\title{
DETERMINATION OF ANTIOXIDANT ACTIVITY, TOTAL PHENOLIC CONTENT, AND TOTAL FLAVONOID CONTENT OF ROOTS, STEM BARK, AND LEAVES OF Elaeocarpus mastersii KING
}

\author{
T. Okselni ${ }^{1}$, A. Santoni ${ }^{1}$, A. Dharma ${ }^{\mathbf{1}}$ and M. Efdi ${ }^{1, *}$ \\ ${ }^{1}$ Department of Chemistry, Andalas University, Padang 25163, West Sumatra, Indonesia \\ *E-mail: maiefdi@sci.unand.ac.id
}

\begin{abstract}
In this research, antioxidant activity, total phenolic, and flavonoid content of n-hexane, ethyl acetate, and methanol fractions of roots, stem bark, and leaves of Elaeocarpus mastersii King were determined by the colorimetric method using DPPH assay (1,1-diphenyl-2-picrylhydrazyl), Folin-Ciocalteu reagent, and aluminum chloride reagent, respectively. Phytochemical screening was evaluated by specific reaction of constituents to the specific reagent. Ethyl acetate fraction had the best value of phenolic content and antioxidant activity among all fractions which the best value was obtained from the leaves $\left(380.99 \pm 2.14 \mathrm{mg} \mathrm{GAE} / \mathrm{g} \mathrm{DW}\right.$ and $\left.\mathrm{IC}_{50} 1.95 \pm 0.01 \mu \mathrm{g} / \mathrm{mL}\right)$ followed by the roots $\left(362.88 \pm 1.89 \mathrm{mg} \mathrm{GAE} / \mathrm{g} \mathrm{DW}\right.$ and $\left.\mathrm{IC}_{50} 2.05 \pm 0.01 \mu \mathrm{g} / \mathrm{mL}\right)$ and the stem bark $(341.89 \pm 3.97 \mathrm{mg} \mathrm{GAE} / \mathrm{g}$ DW and $\mathrm{IC}_{50} 2.36 \pm 0.02 \mu \mathrm{g} / \mathrm{mL}$ ). All fractions of this plant showed the low value of flavonoid content. The phytochemical screening exhibited that this plant was dominated by phenolic and alkaloid compounds. These results demonstrate the great potential of Elaeocarpus mastersii King as a natural antioxidant and active compounds.

Keywords: antioxidant activity, Elaeocarpus mastersii King, total phenolic content, total flavonoid content
\end{abstract}

@ $\operatorname{RASĀYAN}$. All rights reserved

\section{INTRODUCTION}

Free radicals promote oxidative damage on cells, tissues, lipids, proteins, and $\mathrm{DNA}^{1,2}$. Oxidative damage is related to the human disease such as cancer, cardiovascular, rheumatoid arthritis, ischemia/reperfusion, atherosclerosis, diabetes mellitus, and neurodegenerative (Alzheimer's disease and Parkinson's disease). Free radicals can be prevented by the presence of antioxidant agents obtained from synthetic compounds (e.g. butylated hydroxyanisole, butylated hydroxytoluene, propyl gallate, octyl gallate, dodecyl gallate) and natural product ${ }^{2-4}$. Synthetic antioxidants have been suspected as an agent of carcinogenesis, liver damage, and DNA damage when used at high levels ${ }^{5-7}$. Therefore, a natural antioxidant is more desirable to replace the synthetic antioxidant. The natural antioxidant is found in the plant which has secondary metabolites, such as flavonoids, stilbenes, terpenoids, and phenolic compounds ${ }^{8-10}$. Phenolic compounds are categorized as the primary antioxidant agent because the phenolic compounds can donate a hydrogen atom to the radical compounds and produce the stable radical ${ }^{4}$.

Elaeocarpaceae family have a large number of phenolic compounds, especially the genus of Elaeocarpus ${ }^{11-13}$. Previous studies showed that Elaeocarpus genus plants have a great biological activity as an antioxidant ${ }^{12-17}$. Elaeocarpus mastersii King is classified into Elaeocarpus genus that has been used as folk medicine for treatment of diabetic and hypertensive disease. Previous research reported that the $E$. mastersii has phenolic compounds (a derivate of ellagic acid) with their pharmacological properties ${ }^{18}$.

The aim of this research is to determine total phenolic content (TPC), total flavonoid content (TFC), and antioxidant activity of n-hexane, ethyl acetate, and methanol fractions from the roots, stem bark, and leaves of E. mastersii. In addition, it is the first report to determine TPC, TFC, and antioxidant activity from the various fractions and parts of E. mastersii.

Rasayan J. Chem., 11(3), 1211-1216(2018)

http://dx.doi.org/10.31788/RJC.2018.1133058

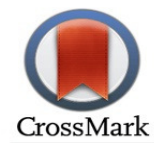


RASĀYAN J. Chem.

Vol. 11 | No. 3 |1211 - 1216 | July - September | 2018

\section{Plant Material}

\section{EXPERIMENTAL}

Roots, stem bark, and leaves of E. mastersii were collected in Riau, Indonesia. The plant was identified at Herbarium of Andalas University with the collection number of ANDA: 040.

\section{Extraction}

The plant materials were extracted by maceration method at room temperature using methanol solvent. The crude extracts of each part were concentrated by a rotary evaporator and partitioned using n-hexane and ethyl acetate solvent.

\section{Determination of Total Phenolic Content}

TPC of the E. mastersii extracts was measured by Folin-Ciocalteu method ${ }^{19}$ with slight modifications. The extract of $100 \mu \mathrm{g} / \mathrm{mL}$ in ethanol solution was added into a test tube containing Folin-Ciocalteu reagent $(10 \%, \mathrm{~V} / \mathrm{V})$ and sodium carbonate $(2 \%, \mathrm{~W} / \mathrm{V})$ with the volume ratio of $0.5: 2.5: 2$. The mixture was shaken and incubated at $45^{\circ} \mathrm{C}$ for $15 \mathrm{~min}$. Absorbance was measured at $765 \mathrm{~nm}$ using spectrophotometer (Apel PD-303S, Japan). Phenolic contents were obtained from the calibration curve of gallic acid $(0-80 \mu \mathrm{g} / \mathrm{mL})$ and expressed as gallic acid equivalent (mg GAE/g) of dry weight.

\section{Determination of Total Flavonoid Content}

TFC was measured by a colorimetric method using aluminum chloride reagent ${ }^{20}$ with slight modifications. The extract was dissolved by ethanol solution $(100 \mu \mathrm{g} / \mathrm{mL})$. The extract solution $(2.0 \mathrm{~mL})$ was mixed with $0.1 \mathrm{~mL}$ of aluminum chloride $(10 \%, \mathrm{~W} / \mathrm{V})$ and $0.1 \mathrm{~mL}$ of sodium acetate $\left(0.1 \mathrm{mmol} . \mathrm{L}^{-1}\right)$. The mixture was shaken and incubated at room temperature for $30 \mathrm{~min}$. Absorbance was measured at 415 $\mathrm{nm}$ using spectrophotometer (Apel PD-303S, Japan). Flavonoid contents were obtained from the calibration curve of rutin $(0-80 \mu \mathrm{g} / \mathrm{mL})$ and expressed as rutin equivalent (mg RE/g) of dry weight.

\section{Antioxidant Activity by DPPH Assay}

The antioxidant activity of the extract was investigated by DPPH assay ${ }^{19}$ with slight modifications. The solution of DPPH in ethanol $\left(1.0 \mathrm{~mL}, 0.1 \mathrm{mmol} . \mathrm{L}^{-1}\right)$ was added into the tube containing $3.0 \mathrm{~mL}$ of extract in various concentrations. The mixture was incubated for $30 \mathrm{~min}$ at room temperature in the dark. The absorbance was measured at $517 \mathrm{~nm}$ using spectrophotometer (Apel PD-303S, Japan). The antioxidant activity was estimated based on the inhibition percentage of radical using the equation:

$$
\% \text { Inhibition }=\left[\left(\mathrm{A}_{\text {control }}-\mathrm{A}_{\text {sample }}\right) \times 100\right] / \mathrm{A}_{\text {control }}
$$

Where A control is the absorbance of control containing all of the reagents except the sample, while A sample is the absorbance of the sample.

\section{Statistical Analysis}

All analyses were done in triplicate and the values were presented as average with their standard deviations (SD). The correlation coefficients (R) between TPC, TFC, and antioxidant activity of the $E$. mastersii extracts were calculated to determine their relationship. Statistical analysis was investigated by One-way analysis of variance (ANOVA) followed by Duncan's multiple range test using SAS (version 9.4) software. $P$-value $<0.05$ was recognized as a significant difference.

\section{Phytochemical Screening}

The secondary metabolites, as phenols, terpenoid, steroid, and alkaloid compounds of the E. mastersii extracts were investigated based on the standard method. ${ }^{21}$

\section{Total Phenolic and Flavonoid Content}

\section{RESULTS AND DISCUSSION}

The phenolic values were obtained from the calibration curve of gallic acid, $y=0.0081 x+0.0024$ with $R^{2}$ $=0.9997$. The flavonoid values were obtained from the calibration curve of rutin, $y=0.0196 x+0.0377$ with $R^{2}=0.9963$. The results are shown in Table- 1 . 
RASĀYAN J. Chem.

Vol. 11 | No. 3 |1211 - 1216 | July - September | 2018

Table-1: Total Phenolic Content and Total Flavonoid Content of the E. mastersii extract

\begin{tabular}{|c|c|c|c|c|c|}
\hline \multirow{4}{*}{$\begin{array}{l}\text { Fraction } \\
\text { n-hexane }\end{array}$} & Part & $\mathrm{TPC}(\mathrm{mg}$ GAE/g DW $) \pm \mathrm{SD}$ & \multicolumn{3}{|c|}{ TFC (mg RE/g DW) \pm SD } \\
\hline & Roots & $21.77 \pm 0.26^{\mathrm{h}}$ & 5.77 & \pm & $0.51^{\mathrm{f}}$ \\
\hline & Stem bark & $15.47 \pm 0.38^{\mathrm{i}}$ & 2.53 & \pm & $0.29^{\mathrm{g}}$ \\
\hline & Leaves & $79.26 \pm 0.33^{\mathrm{g}}$ & 6.62 & \pm & $2.06^{\mathrm{f}}$ \\
\hline \multirow[t]{3}{*}{ Ethyl acetate } & Roots & $362.88 \pm 1.89^{b}$ & 30.09 & \pm & $1.28^{b}$ \\
\hline & Stem bark & $341.89 \pm 3.97^{\mathrm{c}}$ & 18.35 & \pm & $0.78^{\mathrm{d}}$ \\
\hline & Leaves & $380.99 \pm 2.14^{\mathrm{a}}$ & 26.34 & \pm & $0.29^{c}$ \\
\hline \multirow[t]{3}{*}{ Methanol } & Roots & $152.18 \pm 3.56^{\mathrm{f}}$ & 16.14 & \pm & $1.06^{\mathrm{e}}$ \\
\hline & Stem bark & $287.16 \pm 2.14^{\mathrm{d}}$ & 30.94 & \pm & $0.78^{b}$ \\
\hline & Leaves & $273.58 \pm 2.14^{\mathrm{e}}$ & 44.03 & \pm & $0.51^{\mathrm{a}}$ \\
\hline
\end{tabular}

The value was presented as mean $\pm \mathrm{SD}(\mathrm{n}=3)$ and values with different superscript letters imply the significant differences $(P<0.05)$

TPC was measured by Folin-Ciocalteu reagent based on the principle of formation of the blue phosphotungstic-phosphomolybdic complex as the result of a reaction between Folin-Ciocalteu and phenolic compounds ${ }^{22}$. The results showed that E. mastersii extracts had the high amount of phenolic content. The highest phenolic content was obtained from the ethyl acetate fraction for all parts of this plant. In the ethyl acetate and n-hexane fraction, the highest number of phenolic contents was found in the leaves with the value of $380.99 \pm 2.14$ and $79.26 \pm 0.33 \mathrm{mg} \mathrm{GAE} / \mathrm{g} \mathrm{DW}$, whereas the methanol fraction was found in the stem bark (287.16 $\pm 2.14 \mathrm{mg} \mathrm{GAE} / \mathrm{g} \mathrm{DW})$. In general, $\mathrm{n}$-hexane fraction of all parts had the low value of phenolic content. It is related to the polarity properties of phenolic compounds which are more dissolved in the polar solvents. Several previous studies showed that the solvent has a significant effect on the amount of phenolic contents ${ }^{20,23-25}$. Each part of the plant has a variation of phenolic content. It is due to the physiological function of phenolic compounds related to the defense mechanism of plants against biotic and abiotic attack ${ }^{26,27}$.

TFC was investigated by colorimetric method using aluminum chloride reagent based on the formation of a yellow complex between the ion of aluminum $\left(\mathrm{Al}^{3+}\right)$ and the carbonyl and hydroxyl groups of flavonoid ${ }^{28}$. TFC test results showed the low flavonoid value of all parts of E. mastersii which the highest value $(44.03 \pm 0.51 \mathrm{mg} \mathrm{RE} / \mathrm{g} \mathrm{DW})$ was found in leaves of the methanol fraction. It indicated that the flavonoid was the minor compounds of the E. mastersii plant.

\section{Antioxidant Activity by DPPH Assay}

Antioxidant activity of the E. mastersii extract had been examined by DPPH assay. The results (Table-2) showed that most of the extracts had strong antioxidant activity.

Table-2: Antioxidant activity by DPPH assay of the E. mastersii extract

\begin{tabular}{l|l|r}
\hline Fraction & Part & $\mathrm{IC}_{50}(\mu \mathrm{g} / \mathrm{mL}) \pm \mathrm{SD}$ \\
\hline \multirow{2}{*}{-hexane } & Roots & $85.70 \pm 0.52^{\mathrm{e}}$ \\
\cline { 2 - 3 } & Stem bark & $187.11 \pm 1.22^{\mathrm{f}}$ \\
\cline { 2 - 3 } & Leaves & $14.21 \pm 0.05^{\mathrm{d}}$ \\
\hline \multirow{2}{*}{ Ethyl acetate } & Roots & $2.05 \pm 0.01^{\mathrm{a}}$ \\
\cline { 2 - 3 } & Stem bark & $2.36 \pm 0.02^{\mathrm{a}}$ \\
\cline { 2 - 3 } & Leaves & $1.95 \pm 0.01^{\mathrm{a}}$ \\
\hline \multirow{2}{*}{ Methanol } & Roots & $6.38 \pm 0.02^{\mathrm{c}}$ \\
\cline { 2 - 3 } & Stem bark & $2.75 \pm 0.02^{\mathrm{a}}$ \\
\cline { 2 - 3 } & Leaves & $3.21 \pm 0.00^{\mathrm{b}}$ \\
\hline Ascorbic acid & - & $2.44 \pm 0.03$ \\
\hline
\end{tabular}

The value was presented as mean \pm SD $(n=3)$ and values with different superscript letters imply the significant differences $(P<0.05)$

The principle of the DPPH method is to stabilize free radical of DPPH (1,1-diphenyl-2-picrylhydrazyl) with the presence of an electron donor from a hydrogen atom of the phenolic compound. An increase in 
RASĀYAN J. Chem.

Vol. 11 | No. 3 |1211 - 1216 | July - September | 2018

the number of phenolic compounds leads to an increase in the number of $\mathrm{OH}$ group on the aromatic ring, thereby enhancing the ability to inhibit free radicals ${ }^{29}$. The results showed that the ethyl acetate fraction of all parts provided the strongest antioxidant activity among all fractions. In the ethyl acetate and n-hexane fraction, the strongest antioxidant activity was found in the leaves with the $\mathrm{IC}_{50}$ value of $1.95 \pm 0.01$ and $14.21 \pm 0.05 \mu \mathrm{g} / \mathrm{mL}$, whereas the methanol fraction was found in the stem bark ( $\mathrm{IC}_{50} 2.75 \pm 0.02 \mu \mathrm{g} / \mathrm{mL}$ ). Utami et al. ${ }^{13}$ reported that the strongest antioxidant activity of Elaeocarpus floribundus was found in the methanol fraction of stem bark $\left(\mathrm{IC}_{50} 7.36 \pm 0.01 \mu \mathrm{g} / \mathrm{mL}\right)$ and Prihantini et al. ${ }^{17}$ reported the best $\mathrm{IC}_{50}$ value of Elaeocarpus sylvestris $(7.7 \pm 0.8 \mu \mathrm{g} / \mathrm{mL})$ found in the methanol fraction of leaves. It showed that $E$. mastersii have a stronger antioxidant activity than a few species of Elaeocarpus.

\section{Correlation of Phenols, Flavonoid and Antioxidant Activity}

The correlation between TPC, TFC, and antioxidant activity of n-hexane, ethyl acetate, and methanol fractions of $E$. mastersii plant had been investigated by the correlation coefficient $(R)$ using statistical analysis. The results are shown in Table-3.

Table-3: Correlation between TPC, TFC, and Antioxidant Activity of n-Hexane, Ethyl Acetate, and Methanol Fractions of E. mastersii Plant

\begin{tabular}{l|c|c|c}
\hline Fraction & $R_{\text {TPC-TFC }}$ & $R_{\text {TPC-DPPH }}$ & $R_{\text {TFC-DPPH }}$ \\
\hline n-Hexane & 0.63093 & 0.86096 & 0.84534 \\
& $(P=0.01429)$ & $(P=0.00011)$ & $(P=0.00037)$ \\
\hline Ethyl acetate & 0.69262 & 0.96238 & 0.84118 \\
& $(P=0.13012)$ & $(P=1.59 \mathrm{E}-06)$ & $(P=9.82 \mathrm{E}-07)$ \\
\hline Methanol & 0.83266 & 0.99890 & 0.82119 \\
& $(P=0.50240)$ & $(P=5.46 \mathrm{E}-12)$ & $(P=0.00011)$ \\
\hline
\end{tabular}

$R_{\text {TPC-TFC }}$ is correlation coefficient value between phenolic content and flavonoid content $R_{\text {TPC-DPPH }}$ is correlation coefficient value between phenolic content and antioxidant activity $R_{\text {TFC-DPPH }}$ is correlation coefficient value between flavonoid content and antioxidant activity

A correlation analysis between phenolic and flavonoid contents showed that the correlation of n-hexane fraction was found to be $0.63093(P<0.05)$, while the ethyl acetate and methanol fractions did not show the correlation $(P>0.05)$. This result indicated that flavonoid was not the main and major of phenolic compounds from E. mastersii plant.

As shown in Table 3, the correlations of TPC, TFC to the antioxidant activity of E. mastersii plant revealed that TPC had a higher correlation to antioxidant activity than TFC which the highest correlation coefficient $(R)$ value was found to be 0.99890 obtained from the methanol fraction. It indicated that phenolic compounds have an important role in the antioxidant activity of E. mastersii plant.

\section{Phytochemical Screening}

The phytochemical screening had been conducted to determine the secondary metabolite compounds that could be involved in the antioxidant activity of E. mastersii (Table-4). The results are shown in Table- 4 .

Table-4: Phytochemical Screening of the E. mastersii Extract

\begin{tabular}{l|l|c|c|c|c}
\hline \multirow{2}{*}{ Fraction } & \multirow{2}{*}{ Part } & \multicolumn{4}{|c}{ Chemical Constituent } \\
\cline { 3 - 6 } & & Phenols & Terpenoid & Steroid & Alkaloid \\
\hline \multirow{2}{*}{ n-hexane } & Roots & - & - & + & + \\
\cline { 2 - 6 } & Stem bark & - & - & + & + \\
\cline { 2 - 6 } & Leaves & - & - & + & + \\
\hline \multirow{3}{*}{ Ethyl acetate } & Roots & + & - & - & + \\
\cline { 2 - 6 } & Stem bark & + & - & - & + \\
\cline { 2 - 6 } & Leaves & + & - & - & - \\
\hline \multirow{3}{*}{ Methanol } & Roots & + & - & - & - \\
\cline { 2 - 6 } & Stem bark & + & - & - & - \\
\cline { 2 - 6 } & Leaves & + & - & - & + \\
\hline
\end{tabular}

(+) indicates the presence of constituents, (-) indicates the absence of constituents 
RASĀYAN J. Chem.

Vol. 11 | No. 3 |1211 - 1216 | July - September | 2018

The phytochemical screening is based on the specific reaction of each compound to the specific reagent ${ }^{21}$. The results showed that E. mastersii plant was dominated by phenolic and alkaloid compounds (Table 4). Alkaloids are the most common compounds that had been isolated of Elaeocarpus genus such as $( \pm)$ elaeocarpine, ( \pm -isoelaeocarpine, ( \pm )-3-oxoisoelaeocarpine, $( \pm)$-elaeocarpine N-oxide, and (-)isoelaeocarpiline of Elaeocarpus sphaericus ${ }^{30}$, elaeocarpenine of Elaeocarpus fuscoides ${ }^{31}$, and habbemines $\mathrm{A}$ and $\mathrm{B}$ of Elaeocarpus habbemensis ${ }^{32}$. Alkaloids are also known to provide a positive correlation in the antioxidant activity. ${ }^{33,34}$

\section{CONCLUSION}

This study revealed that the ethyl acetate and methanol fractions of all parts of $E$. mastersii have strong antioxidant activity and a great potential as a source of natural antioxidant. This ability could be due to the presence of phenolic compounds. The ethyl acetate fraction has the best value of phenolic content and antioxidant activity of $E$. mastersii. Therefore, the ethyl acetate fraction may have more active compounds among all fractions.

\section{ACKNOWLEDGMENT}

The authors are thankful to the Ministry of Research and Technology, Indonesia for the project of "Master Program of Education Leading to Doctoral Degree for Excellent Graduate (PMDSU)" for funding the financial support (Grant number: 059/SP2H/LT/DRPM/IV/2017).

\section{REFERENCES}

1. A.P. Wickens, Respiration Physiology, 128, 379 (2001), DOI: 10.1016/S0034-5687(01)00313-9

2. M. Valko, D. Leibfritz, J. Moncol, M.T.D. Cronin, M. Mazur, and J. Telser, Int. J. Biochem. Cell Biol., 39, 44 (2007), DOI: 10.1016/j.biocel.2006.07.001

3. A. Augustyniak, G. Bartosz, A. Čipak, G. Duburs, L'. Horáková, W. Łuczaj, M. Majekova, A.D. Odysseos, L. Rackova, E. Skrzydlewska, M. Stefek, M. Štrosova, G. Tirzitis, P.R. Venskutonis, J. Viskupicova, P.S. Vraka, and N. Žarkovic, Free Radic. Res., 44(10), 1216 (2010), DOI: 10.3109/10715762.2010.508495

4. F. Shahidi and P. Ambigaipalan, J. Funct. Foods, 18, 820 (2015), DOI: 10.1016/j.jff.2015.06.018

5. J.E.N. Dolatabadi and S. Kashanian, Food Res. Int., 43, 1223 (2010), DOI: 10.1016/j.foodres.2010.03.026

6. H.C. Grice, Food Chem. Toxicol., 26(8), 717 (1988), DOI: 10.1016/0278-6915(88)90072-5

7. H.P. Witschi, Food Chem. Toxicol., 24(10), 1127 (1986), DOI: 10.1016/0278-6915(86)90298-X

8. A. Matkowski, Biotechnol. Adv., 26, 548 (2008), DOI: 10.1016/j.biotechadv.2008.07.001

9. D. Shahwar and M.A. Raza, Asian Pac. J. Trop. Biomed., 2(7), 547 (2012), DOI: 10.1016/S22211691(12)60094-X

10. J.M. Lorenzo and P.E.S. Munekata, Asian Pac. J. Trop. Biomed., 6(8), 709 (2016), DOI: 10.1016/j.apjtb.2016.06.010

11. S. Hardainiyan, B.C. Nandy, and R. Saxena, Int. J. Pharm. Pharm. Sci., 7(6), 415 (2015).

12. S. Saikia, N.K. Mahnot, and C.L. Mahanta, Food Biosci., 13, 15(2016), DOI: 10.1016/j.fbio.2015.11.003

13. R. Utami, N. Khalid, M.A. Sukari, M. Rahmani, A.B. Abdul, and Dachriyanus, Pak J. Pharm. Sci., 26, 245 (2013).

14. M.N. Parvin, S. Sarwar, S.A. Chowdhury, H.M. Zakaria, and N.H. Huda, Stamford J. Pharm. Sci., 2(2), 86 (2009), DOI: 10.3329/sjps.v2i2.5829

15. R. Shamna, J.M. Sasikumar, E.S. Adithya, P.H. Christabel, and M.S. Lakshmi, Food, 5(1), 96 (2011).

16. L. Jayasinghe, N.R. Amarasinghe, B.G.S. Arundathie, G.K. Rupasinghe, N.H.A.N. Jayatilake, and Y. Fujimoto, Nat. Prod. Res., 26, 717 (2012), DOI: 10.1080/14786419.2010.551514

17. A.I. Prihantini, S. Tachibana, and K. Itoh, Procedia. Environ. Sci., 28, 758 (2015), DOI: 10.1016/j.proenv.2015.07.089

18. A. Ito, H. Chai, D. Lee, L.B.S. Kardono, S. Riswan, N.R. Farnsworth, G.A. Cordell, J.M. Pezzuto, and A.D. Kinghorn, Phytochemistry, 61, 171 (2002), DOI: 10.1016/S0031-9422(02)00232-7

19. S. Sen, B. De, N. Devanna, and R. Chakraborty, Chin. J. Nat. Med., 11(2), 149 (2013), DOI: 1215 
RASĀYAN J. Chem.

Vol. 11 | No. 3 |1211 - 1216 | July - September | 2018

10.1016/S1875-5364(13)60042-4

20. Q.D. Do, A.E. Angkawijaya, P.L. Tran-Nguyen, L.H. Huynh, F.E. Soetaredjo, S. Ismadji, and Y. Ju, J. Food Drug Anal., 22(3), 296(2013), DOI: 10.1016/j.jfda.2013.11.001

21. J.B. Harborne, Phytochemical Methods: A Guide to Modern Technique of Plant Analysis, Chapman and Hall, New York (1973), DOI: 10.1007/978-94-009-5921-7

22. P. Schofield, D.M. Mbugua, and A.N. Pell, Animal Feed Science and Technology, 91, 21 (2001), DOI: $10.1016 / \mathrm{S} 0377-8401(01) 00228-0$

23. F. Barros, L. Dykes, J.M. Awika, and L.W. Rooney, J. Cereal. Sci., 58(2), 305 (2013), DOI: 10.1016/j.jcs.2013.05.011

24. S.A.O. Santos, C.S.R. Freire, M.R.M. Domingues, A.J.D. Silvestre, and C.P. Neto, J. Agric. Food Chem., 59, 9386 (2011), DOI: 10.1021/jf201801q

25. A. Fernández-Agulló, E. Pereira, M.S. Freire, P. Valentão, P.B. Andrade, J. González-álvarez, and J.A. Pereira, Ind. Crops. Prod., 42, 126 (2013), DOI: 10.1016/j.indcrop.2012.05.021

26. L.J. Jing, M. Mohamed, A. Rahmat, and M.F.A. Bakar, J. Med. Plants. Res., 4(1), 27 (2010), DOI: 10.5897/JMPR09.308

27. A. Bhattacharya, P. Sood, and V. Citovsky, Mol. Plant Pathol., 11(5), 705 (2010), DOI: 10.1111/J.1364-3703.2010.00625.X

28. M. Popova, V. Bankova, D. Butovska, V. Petkov, B.N. Damyanova, A.G. Sabatini, G.L. Marcazzan, and S. Bogdanov, Phytochemical Analysis, 15, 235 (2004), DOI: 10.1002.pca.777

29. M.G. Miguel, Flavour Fragr. J., 25, 291 (2010), DOI: 10.1002/ffj.1961

30. C. Zhou, X. Wang, J. Mo, J. Zhang, and L. Gan, Helv. Chim. Acta., 94, 347 (2011), DOI: 10.1002/hlca.201000200

31. P.L. Katavic, D.A. Venables, T. Rali, and A.R. Carroll, J. Nat. Prod., 70, 872 (2007), DOI: 10.1021/np060607e

32. P.L. Katavic, D.A. Venables, T. Rali, and A.R. Carroll, J. Nat. Prod., 70, 866 (2007), DOI: 10.1021/np060577f

33. S. Khamtache-abderrahim, M. Lequart-Pillon, E. Gontier, I. Gaillard, S. Pilard, D. Mathiron, H. Djoudad-Kadji, and F. Maiza-Benabdesselam, Ind. Crop. Prod., 94, 1001 (2016), DOI: 10.1016/j.indcrop.2016.09.016

34. A. Zahari, A. Ablat, Y. Sivasothy, J. Mohamad, M.I. Choudhary, and K. Awang, Asian Pac. J. Trop. Med., 9(4), 328 (2016), DOI: 10.1016/j.apjtm.2016.03.008

[RJC-3058/2018] 